\title{
PENGARUH BERBAGAI JENIS ALGA MIKRO PADA PERTUMBUHAN LARVA PLUTEUS BULU BABI Echinometra mathaei TIPE A HASIL FERTILISASI BUATAN
}

\section{(Effects on Various Types of Micro Algae Diets on Growth of Pluteus Larvae Echinometra mathaei Type A from Induced Fertilization)}

\author{
Muhlis Alamrie ${ }^{1}$, John A. Lalita ${ }^{1}$, Erly Kaligis ${ }^{1}$ \\ ${ }^{1}$ Program Studi IImu Kelautan,Fakultas Perikanan dan IImu Kelautan Universitas Sam \\ Ratulangi, Manado
}

\begin{abstract}
This study was designed to assess the effects of different micro algae diets on growth of Echinometra mathaei pluteus larvae. Broodstrock of E. matthei was collected from Tongkaina coastal waters. Fertilization was induced by taking $1 \mathrm{ml}$ egg and sperm cells from each individual. Sea urchin larvae was fed with three different types of micro algae, i.e. Nannochloropsis oculata $\left(3 \times 10^{6}\right.$ cells $\left./ \mathrm{ml}\right)$, Tetraselmis sp. $\left(2 \times 10^{6}\right.$ cells $\left./ \mathrm{ml}\right)$, and Prochloron sp $\left(1 \times 10^{6}\right.$ cells / ml) during 70 hours of observations. The observations were made every 10 hours by taking 5 individuals of each dish. Results of statistical tests by using one-way analysis ANOVA indicated that the variety of micro algae diets affects on growth of antero-lateral arm of larvae. Use of $N$. oculata diets affects more on the growth of anterolateral arm compared to other micro algal treatments.
\end{abstract}

Keywords: Echinometra mathaei, micro algae, anterolateral

Penelitian ini didesain untuk mengevaluasi pengaruh dari pakan alga mikro berbeda terhadap karakteristik pertumbuhan larva pluteus Echinometra mathaei. Sampel E. mathaei diambil dari perairan pantai Tongkaina. Tahap fertilisasi buatan dilakukan dengan mengambil masing-masing $1 \mathrm{ml}$ sel telur dan sel sperma. Larva bulu babi diberi perlakuan 3 jenis alga mikro yakni $N$. oculata $\left(3 \times 10^{6} \mathrm{sel} / \mathrm{m}\right)$, Tetraselmis sp. $\left(1,2 \times 10^{6} \mathrm{sel} / \mathrm{ml}\right)$., dan Prochloron $\mathrm{sp}$. $\left(1 \times 10^{6} \mathrm{sel} / \mathrm{ml}\right)$ selama 70 jam. Pengamatan dilakukan setiap 10 jam dengan mengambil 5 individu dari tiap petri. Hasil uji statistik menggunakan analisis ragam satu arah, mengindikasikan bahwa perlakuan berbagai pakan alga mikro mempengaruhi pertumbuhan panjang lengan anterolateral larva. Perlakuan alga mikro $N$. oculata memberi pengaruh yang lebih baik terhadap pertumbuhan panjang lengan anterolateral daripada perlakuan alga mikro lain.

Kata kunci: Echinometra mathaei, alga mikro, anterolateral

\section{PENDAHULUAN}

Bulu babi termasuk dalam Filum Echinodermata, Kelas Echinoidea yang menghuni perairan laut pada segala jenis dasar berkisar dari daerah pasang surut hingga kedalaman 5000 meter dan umumnya dijumpai pada zona litoral, yaitu dari batas pasang daerah tertinggi sampai paparan benua (Hyman, 1955). Bentuk bulu babi yaitu bangun segi lima yang menyerupai oval dan cakram, tertutup cangkang endoskeleton dengan duri yang dapat digerakkan.

Bulu babi telah dimanfaatkan untuk berbagai keperluan, seperti gonad sebagai makanan bergizi tinggi (Shokita, dkk, 1991), gamet-gamet bulu babi dalam penelitian bioreproduksi, fisiologi dan penelitian toksikologi (Czihak, 1975; Giudice, 1985), embrio bulu babi dalam uji biologis untuk pemantauan lingkungan dan sebagai indikator kualitas air (Dinnel, 
1994), serta larva bulu babi sebagai pakan dalam pembenihan ikan maupun udang (Ma'ruf, 1996).

Teknik fertilisasi buatan bulu babi mulai dilakukan oleh Oscar Hertwig di tahun 1876 kemudian terus berkembang hingga saat ini (Le Gall, 1990). Selama proses perkembangan embrio, perlu penanganan yang baik agar embrio (larva pluteus) dapat bertahan hidup lebih lama. Salah satu terobosan yang dilakukan yakni melalui pemberian berbagai alga mikro. (Lengkong, 2002; Ririmasse 2005). Pemberian alga mikro sebagai pakan karena secara anatomi larva pluteus bulu babi telah mempunyai organ pencernaan sehingga memiliki kemampuan untuk mengkonsumsi pakan. Namun, pengaruh yang ditimbulkan oleh berbagai pakan alga mikro terhadap pertumbuhan panjang larva bulu babi jenis Echinometra mathaei belum diketahui,. Penelitian ini bertujuan untuk membandingkan karakteristik pertumbuhan pluteus (panjang lengan postoral, panjang lengan anterolateral dan panjang total) larva bulu babi yang diberi berbagai pakan alga mikro.

\section{METODE PENELITIAN}

\section{a. Pengadaan Alga Sebagai Pakan Larva Bulu Babi}

Air laut yang digunakan untuk media kultur berasal dari perairan terdekat yang masih relatif bersih dan jauh dari pemukiman. Selanjutnya air laut ini disaring dengan kertas saring milipore dengan bantuan aspirator Asp 13, kemudian diencerkan dengan aquades untuk mendapatkan salinitas 20 ppt. Air laut tersebut dijadikan pelarut terhadap senyawa-senyawa yang mensuplai nutrien bagi pertumbuhan alga mikro, dengan komposisi yang tertera pada Tabel berikut ini.
Tabel 1. Komposisi media kultur alga (Hirata, 1975)

\begin{tabular}{|l|c|c|}
\hline No. & Bahan & $\begin{array}{c}\text { Konsentrasi } \\
(\mathrm{ppm})\end{array}$ \\
\hline 1. & $\left(\mathrm{NH}_{4}\right)_{2} \mathrm{SO}_{4}$ & 122,6 \\
2. & $\mathrm{Na}_{2} \mathrm{HPO}_{4} 12 \mathrm{H}_{2} \mathrm{O}$ & 23 \\
3. & Clewat 32 & 15 \\
\hline
\end{tabular}

Alga mikro yang digunakan sebagai pakan larva bulu babi adalah Nannochloropsis oculata, Tetraselmis sp., Prochloron sp. Sebelum digunakan sebagai pakan larva bulu babi, alga mikro terlebih dahulu disentrifus dengan kecepatan 3000 rpm selama 10 menit. Bagian supernatan dibuang dan suspensi diambil sebagai pakan larva bulu babi. Suspensi ini diencerkan dengan air laut steril.

\section{b. Pengambilan dan Penanganan Sampel}

Sampel bulu babi diambil dari perairan pantai Tongkaina pada saat air laut berada pada surut terendah. Di laboratorium, sampel dimasukkan ke dalam akuarium yang berisi air laut pada salinitas yang sama dengan perairan alami (30 ppt) dan diberi aerasi dengan menggunakan aerator. Bulu babi tersebut diberi makan lamun agar dapat bertahan hidup hingga saat dilakukan fertilisasi buatan. Jika ada bulu babi yang mati maka dikeluarkan dari akuarium.

\section{c. Fertilisasi Buatan}

Sampel yang digunakan dibersihkan dengan air tawar dan duriduri yang ada pada permukaan tubuh bulu babi digunting, kemudian dibilas dengan air laut. Selanjutnya bulu babi dibelah dengan menggunakan gunting pada bagian oral hingga gonadnya kelihatan. Setelah itu bulu babi dibersihkan dari kotoran hasil pembedahan dengan menggunakan air laut steril sebelum diambil gonadnya. 


\begin{abstract}
Agar gonad betina mengeluarkan telur, maka dirangsang dengan menginjeksi $0,5 \mathrm{M} \mathrm{KCl}$ pada bagian oral bulu babi yang telah dibelah. Telur yang keluar kemudian ditampung pada gelas beker yang berisi air laut steril. Cara ini berdasarkan metode Tyler (Amy, 1983). Telur bulu babi ini kemudian dicuci sebanyak tiga kali. Untuk sperma, penanganan dikeluarkan langsung dengan pinset dan ditampung pada cawan petri. Sebelum fertilisasi dilakukan sperma terlebih dahulu diencerkan dalam air laut steril. Fertilisasi buatan dimulai dengan mengambil $1 \mathrm{ml}$ sel telur dalam gelas beker menggunakan pipet, kemudian sel telur ditampung pada gelas arloji yang berisi air laut steril. Sperma sebanyak $1 \mathrm{ml}$ sel yang sudah diencerkan tadi diambil dengan pipet dan diteteskan ke dalam gelas arloji yang sudah berisi sel telur. Setelah itu diamati di bawah mikroskop. Jika terbentuk membran fertilisasi, maka ini dicuci sebanyak dua kali. Embrio bulu babi kemudian dipisahkan ke dalam tiga petridish (tiga ulangan) menurut jenis pakan yang diberikan. Ke dalam tiap petri, dipipet satu tetes dengan perkiraan jumlah embrio sekitar 100 individu.
\end{abstract}

Alga mikro yang diberikan sebagai pakan memiliki kepadatan: $3 \times 10^{6} \mathrm{sel} / \mathrm{ml}$ (Nannochloropsis oculata). $2 \times 10^{6} \mathrm{sel} / \mathrm{ml}$ (Tetraselmis sp.) dan $1 \times 10^{6} \mathrm{sel} / \mathrm{ml}$. (Prochloron sp.).

Pengamatan terhadap embrio bulu babi dilakukan di bawah mikroskop dengan melihat apakah terjadi pembuahan atau tidak. Pengamatan dimulai pada tahap prisma yang diberi perlakuan alga mikro berbeda. Waktu pengamatan setiap 10 jam sekali selama 70 jam, dengan memindahkan 5 Individu yang diambil dari setiap petridish, kemudian dimasukan ke dalam multiwell plate untuk diamati.

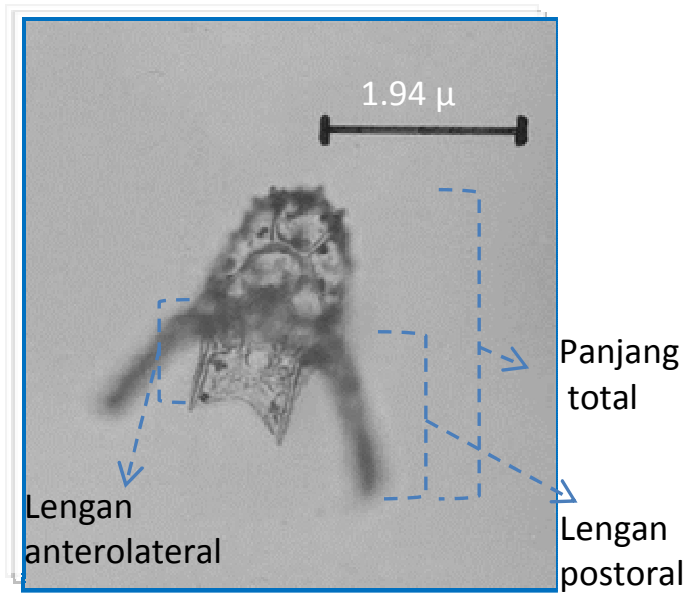

Gambar 1. Larva pluteus E. mathaei dan parameter yang diukur

Parameter yang diukur adalah panjang lengan postoral, panjang lengan anterolateral, dan panjang total (Gambar 1). Pengukuran dilakukan dengan menggunakan alat ukur pada mikroskop. Nilai yang didapat dari hasil pengukuran dikalibrasikan ke dalam panjang $(\mu)$.

Untuk mengetahui apakah perlakuan memberikan pengaruh yang sama atau tidak terhadap pertumbuhan embrio (larva pluteus), maka dilakukan analisis ragam klasifikasi satu arah (Walpole, 1990). Data yang diolah adalah data pertumbuhan panjang lengan postoral, panjang lengan anterolateral, dan panjang total larva bulu babi.

\section{HASIL DAN PEMBAHASAN}

Hasil pengamatan pengaruh pemberian tiga jenis alga mikro terhadap pertumbuhan diukur terhadap panjang lengan postoral, panjang lengan anterolateral, dan panjang total (panjang lengan dan panjang badan) larva bulu babi.

Rata-rata pertumbuhan panjang lengan postoral dari jam ke-0 sampai pada jam ke-70 meningkat (Gambar 2). 


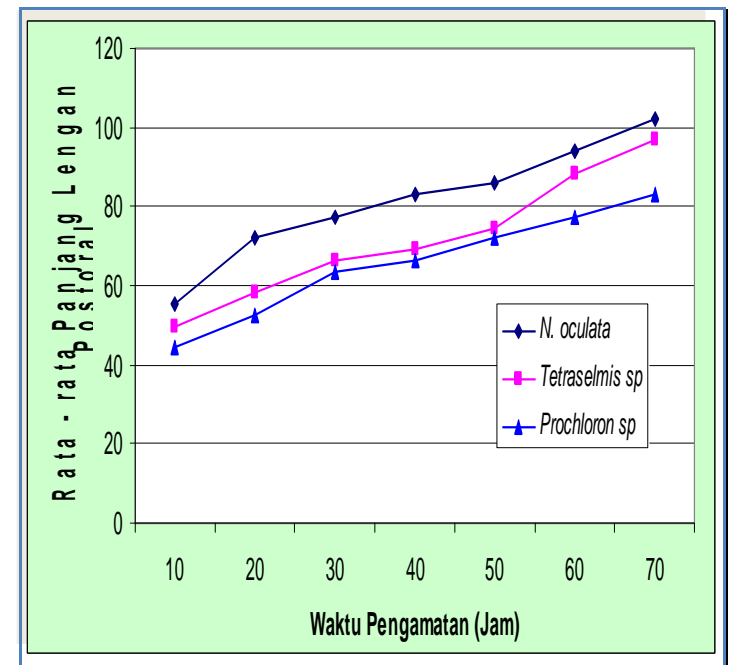

Gambar 2. Rata-rata panjang lengan postoral larva bulu babi $E$. mathaei yang diberi berbagai pakan alga mikro

Lengan postoral larva bulu babi E. mathaei yang diberi berbagai pakan alga mikro mulai mulai terlihat pada pengamatan jam ke-10. Pada jam tersebut larva yang mengkonsumsi alga mikro N. oculata, Tetraselmis sp. dan Prochloron sp. sudah memiliki lengan postoral. Grafik tersebut menunjukkan bahwa sampai pada jam ke-70 larva bulu babi yang diberi alga mikro $N$. oculata mempunyai rata-rata pertumbuhan lengan postoral lebih tinggi yaitu 102,4 $\mu$, kemudian disusul oleh larva yang diberi alga mikro Tetraselmis sp. yaitu 96,8 $\mu$, serta larva yang diberi alga mikro Prochloron sp. yaitu $83,0 \mu$.

Panjang lengan anterolateral belum menunjukkan adanya pertumbuhan hingga jam ke-10 pada larva yang mengkonsumsi 3 jenis alga mikro (Gambar 3). Pertumbuhan mulai terlihat pada jam ke-20, dan pada larva yang diberi pakan alga mikro $N$. oculata dan Tetraselmis sp. nilai rata-rata lengan anterolateral masing-masing $27,7 \mu$ dan $24,9 \mu$. Sedangkan larva yang diberi pakan Prochloron sp. relatif lebih rendah yaitu $19,4 \mu$.

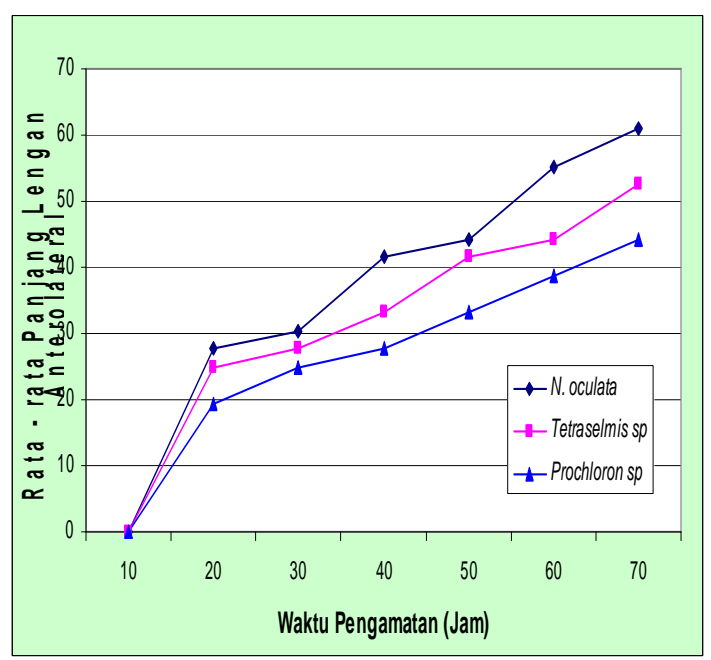

Gambar 3. Rata-rata panjang lengan anterolateral larva bulu babi $E$. mathaei yang diberi berbagai pakan alga mikro

Rata-rata pertumbuhan total larva bulu babi terlihat semakin bertambah (Gambar 4). Pertumbuhan total larva bulu babi yang diberi alga mikro $N$. oculata mempunyai peningkatan yang cepat antara jam ke-10 dan jam ke-20 yakni $69,2 \mu$ dan 146,6 $\mu$, dan untuk larva yang diberi alga mikro Tetraselmis sp. pertumbuhan total meningkat antara jam ke-30 dan jam ke-40 sebesar 157,7 $\mu$ dan 163,2 $\mu$. Hal yang sama juga terjadi pada larva yang diberi Prochloron sp. pertumbuhan total meningkat antara jam ke-30 dan jam ke-40 yakni 143,9 $\mu$ dan $154,9 \mu$.

Berdasarkan analisis statistik, perlakuan tiga jenis alga mikro memberi pengaruh yang sama pada pertumbuhan panjang lengan postoral dan panjang total larva bulu babi, sedangkan untuk panjang lengan anterolateral perlakuan pemberian pakan alga mikro menunjukkan pengaruh yang berbeda.

Hasil uji beda nyata terkecil (BNT) $5 \%$ perlakuan alga mikro $N$. oculata memberikan pengaruh yang berbeda pada pertumbuhan panjang lengan 


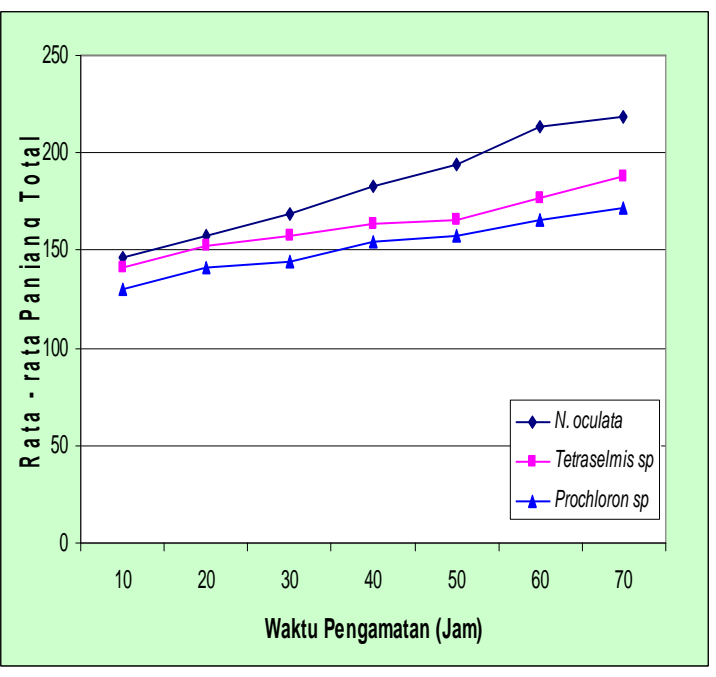

Gambar 4. Rata-rata panjang total larva bulu babi $E$. mathaei yang diberi berbagai pakan alga mikro

anterolateral larva bulu babi, kemudian alga mikro Tetraselmis sp., sedangkan untuk larva yang mengkonsumsi pakan Prochloron sp. kurang memberikan pengaruh nyata terhadap panjang lengan anterolateral. Ririmasse (2005) juga melaporkan bahwa pakan alga mikro $N$. oculata memberi hasil yang lebih baik terhadap pertumbuhan panjang larva bulu babi Salmacis belli dibandingkan Chlorella sp. dan Tetraselmis sp.

Perbedaan pertumbuhan panjang larva pluteus bulu babi yang diberi tiga jenis pakan alga mikro dipengaruhi komposisi gizi dan ukuran dari masingmasing alga mikro. Keunggulan alga mikro $N$. oculata dibanding dengan alga mikro Tetraselmis sp. dan Procholoron sp. karena $N$. oculata memiliki kandungan vitamin B12, protein, dan kandungan asam lemak yang tinggi yaitu Elcosapentaenoic Acid (EPA) sebesar $30,5 \%$, DHA dan kandungan omega 3 HUFAS (Highly Unsaturated Fatty Acid) sebesar 40,7\% (Thahjo, dkk, 2002). Diduga kandungan nutrien yang tinggi mempengaruhi pertumbuhan panjang lengan anterolateral larva pluteus E. mathaei.

\section{KESIMPULAN}

Dari hasil penelitian dapat disimpulkan bahwa perlakuan alga mikro memberikan pengaruh nyata terhadap pertumbuhan panjang anterolateral. Diantara ketiga jenis alga mikro, $N$. oculata memberikan pengaruh lebih besar terhadap panjang lengan anterolateral, dibandingkan alga mikro Tetraselmis sp. dan Prochloron sp.

\section{DAFTAR PUSTAKA}

Amy, R.L. 1983. Gamete Sizes and Development Time Tables of Five Tropical Sea Urchins (Buletin of Marine Science vol.33). Hal 173176.

Czihak, G. 1975. The Sea Urchin Embryo (Biochemistry and Morphogenesis). Spinger-Verlag. New York.

Dinnel, P. A. 1994. Toxicity Testing in The Marine Enviroment. SNCLavalin International. Inc. LPIU. University of Riau Pekan Baru.

Guidice, G. 1985. The Urchin Embryo. University Palermo. Hal 3-23.

Hirata, H. 1975. Preliminary Report On The Photoperiodic Acclimatitation For Growth of Chlorella. Tells In Syncronised Culture. Kagoshima University. Vol 24. Hal 1-6.

Hyman, L.H. 1955. The Invertebrate Echinodermata. The Coelonate Bilateria. Volume IV. Mc Graw. Hill Book Company, Inc. New York. Toronto. London.

Le Gall, P. 1990. Culture Of Echinoderms. Centre regional d' Etudes Cotiers. Station Marine, Ruede commandant Charcot, 14530 Luc sur Mer. France. 
Lengkong. R. H.M.2002. Fertilisasi Buatan dan Perkembangan Awal Embrio Bulu Babi Tripneustes gratilla Yang Diberi Pakan Alga Mikro Berbeda. Skripsi Fakultas Perikanan dan IImu Kelautan UNSRAT Manado. 57 hal.

Ma'ruf, 1996. Prosiding Seminar Hasil Penelitian IImu Kelautan. Fakultas Perikanan Institut Pertanian Bogor. Hal 171-172.

Ririmasse, F. 2005. Pengaruh Berbagai Jenis Alga Mikro Pada Pertumbuhan Larva Pluteus Bulu Babi Salmacis belli Hasil Fertilisasi Buatan. Skripsi Fakultas Perikanan dan IImu Kelautan UNSRAT Manado. 48 hal.

Shokita, S. Kakasu, K, Tomori, A and Toma , T. 1991. Aquaculture in Tropical Areas. dalam : $\mathrm{M}$. Yamaguchi (Edition in English). Midori Shibo Co, Ltd. Tokyo. Japan. Hal 313-327.

Tjahjo, W, L. Erawati, dan H. Santoso. 2002. Biologi Fitoplankton. Dalam: Budidaya Fitoplankton dan Zooplankton. Balai Budidaya Laut Lampung. Ditjenkan Budidaya. Hal 3-9.

Walpole, R. E. 1990. Introduction to Statistics. MacMillan Publishing Co. Inc, New York. 